\title{
Integracja handlowa a synchronizacja cykli koniunkturalnych Polski i Unii Europejskiej
}

\begin{abstract}
Piotr Misztal*
Analiza stopnia synchronizacji wahań koniunkturalnych gospodarek stata się wspótcześnie kluczowa kwestiq $w$ dyskusji na temat procesów integracji gospodarczej krajów. Szczególne zainteresowania ekonomistów zwiazane sa z kwestiq analizy występowania procesów konwergencji (zbieżności) oraz dywergencji (rozbieżności) cykli koniunkturalnych w Unii Europejskiej. Jednym z czynników determinujacych zbieżność cykli koniunkturalnych gospodarek jest intensywność oraz struktura wymiany handlowej krajow. Celem niniejszego opracowania jest analiza oddziatywania handlu międzynarodowego na synchronizację cykli koniunkturalnych Polski i Unii Europejskiej w okresie 1995-2011. W pracy wykorzystano metodę badawcza oparta na studiach literaturowych z zakresu makroekonomii i finansów międzynarodowych oraz metody ekonometryczne (modele wektorowej autoregresji - Vector Autoregression Model). Wyniki przeprowadzonych badań empirycznych wskazuja, że wzrost obrotów handlowych niekoniecznie prowadzi do zwiększenia synchronizacji cykli koniunkturalnych analizowanych gospodarek. Wplyw wzrostu handlu krajów na synchronizację ich cykli koniunkturalnych zależy nie tylko od intensywności wymiany handlowej, lecz także od struktury obrotów handlowych.
\end{abstract}

Słowa kluczowe: cykl koniunkturalny, integracja gospodarcza, handel zagraniczny.

Nadesłany: 15.06.2014 | Zaakceptowany do druku: 05.09.2014

\section{Trade integration and business cycles synchronization of Poland and the European Union}

Analysis of the synchronization of economic fluctuations has become nowadays a key issue in the debate on the process of economic integration. Special interest of economists are related to the issue of the analysis of convergence and divergence processes of business cycles in the European Union. One of the factors determining the convergence of business cycles of economies is the intensity and structure of foreign trade. The purpose of this paper is to analyze the impact of international trade on the synchronization of business cycles between Poland and the European Union in the period 1995-2011. In the study were used a research methods based on literature studies in macroeconomics and international finance and econometric methods (Vector Autoregression Model). The results of empirical studies indicate that the increase in trade does not necessarily lead to increase of business cycles synchronization in analyzed economies. The impact of external trade on the business cycles synchronization depends not only on the intensity of trade, but mainly on the commodity structure of foreign trade.

Keywords: business cycle, economic integration, foreign trade.

Submitted: 15.06.2014 | Accepted: 05.09.2014

JEL: E32, F15, P33.

\footnotetext{
Prof. UJK, dr hab. Piotr Misztal - Uniwersytet Jana Kochanowskiego w Kielcach, Wydział Zarządzania i Administracji.

Adres do korespondencji: Uniwersytet Jana Kochanowskiego w Kielcach, ul. Żeromskiego 5, 25-369 Kielce; e-mail: misztal@tkdami.net.
} 


\section{Wprowadzenie}

Analiza stopnia synchronizacji wahań koniunkturalnych gospodarek, czyli korelacji cyklicznego komponentu produktu krajowego brutto (PKB) stała się współcześnie kluczową kwestią w dyskusji na temat procesów integracji gospodarczej krajów. Szczególne zainteresowania ekonomistów związane są z kwestią analizy występowania procesów konwergencji (zbieżności) oraz dywergencji (rozbieżności) cykli koniunkturalnych w Unii Europejskiej, w tym w szczególności w strefie euro. Stąd pojawia się pytanie: czy cykle koniunkturalne w Unii Europejskiej stają się w coraz większym, czy coraz mniejszym stopniu zsynchronizowane w czasie? Jeśli rzeczywiście występuje proces dywergencji gospodarczej to prowadzenie wspólnej polityki gospodarczej, np. polityki pieniężnej, może nie być jednakowo efektywne $\mathrm{z}$ punktu widzenia pojedynczych krajów lub regionów Unii Europejskiej.

Jednym z czynników determinujących zbieżność cykli koniunkturalnych gospodarek jest intensywność oraz struktura wymiany handlowej krajów. Jednakże w świetle istniejącej teorii ekonomii wpływ wymiany handlowej dwóch krajów na synchronizacje ich cykli koniunkturalnych nie jest jednoznaczny. Kenen (1969) jako pierwszy sugerował, że stosunkowo wysoko zdywersyfikowane gospodarki, mające duży udział handlu wewnątrzgałęziowego (IntraIndustry Trade) w ich całkowitej wymianie handlowej, stosunkowo rzadziej doświadczają szoków asymetrycznych. Przeciwnie uważał Krugman (1991), który twierdził, że podatność kraju na występowanie szoków asymetrycznych zwiększa się wraz ze wzrostem stopnia integracji gospodarek, prowadzącej do wzrostu ich specjalizacji (rys. 1).

Te dwa przeciwstawne poglądy dotyczące wpływu ściślejszej integracji handlowej krajów na ich specjalizację i zbieżność cykli koniunkturalnych są znane jako poglądy odpowiednio Komisji Europejskiej oraz Krugmana.

\section{Istota i główne determinanty synchronizacji cykli koniunkturalnych}

Stopień synchronizacji cykli koniunkturalnych dwóch krajów lub regionów definiuje się jako zbieżność stóp wzrostu gospodarczego w czasie przejawiającą się korelacją cyklicznego komponentu realnego PKB. Stopień synchronizacji cykli koniunkturalnych zdeterminowany jest wieloma czynnikami o charakterze endogenicznym. Do najważniejszych czynników endogenicznych zalicza się przy tym intensywność wymiany handlowej, stopień podobieństwa struktur gospodarczych, stopień podobieństwa polityki pieniężnej i fiskalnej oraz stopień integracji finansowej.

Zgodnie z ujęciem teoretycznym może występować dwukierunkowy wpływ integracji handlowej na korelację cykli koniunkturalnych. $\mathrm{Z}$ jednej strony, gdy dominującym czynnikiem zmian koniunkturalnych w kraju jest kanał popytowy, wówczas wzrost stopnia integracji handlowej krajów może przyczynić się do zwiększenia stopnia

Rysunek 1. Wpływ integracji handlowej na dywergencję cykli koniunkturalnych w świetle poglądów Krugmana i Komisji Europejskiej

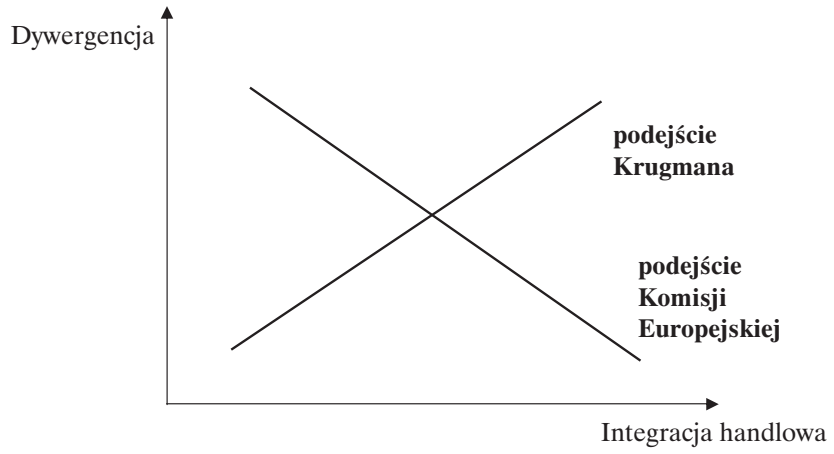

Źródło: Grigoli (2011).

Wydział Zarządzania UW DOI 10.7172/1733-9758.2014.17.6 
korelacji cykli koniunkturalnych krajów. Z drugiej zaś - gdy dominującą siłą oddziałującą na cykl koniunkturalny są czynniki związane $\mathrm{z}$ daną gałęzią przemysłu, wówczas wzrost obrotów handlowych między krajami może doprowadzić do zmniejszenia stopnia korelacji cykli koniunkturalnych lub do jego zwiększenia w zależności od znaczenia wymiany wewnątrz- lub międzygałęziowej.

Jeżeli w obrotach handlowych krajów dominuje handel międzygałęziowy, to wzrost specjalizacji w różnych gałęziach przemysłu sprawia, że oddziaływanie integracji handlowej na synchronizację cykli koniunkturalnych jest negatywne. Jeśli z kolei w obrotach handlowych krajów dominuje wymiana wewnątrzgałęziowa, to struktura towarowa handlu analizowanych krajów jest zbliżona, co może powodować pozytywny wpływ integracji handlowej na synchronizację cykli koniunkturalnych (rys. 2).

Reasumując, całkowity wpływ wzrostu intensywności handlu międzynarodowego na korelację cykli koniunkturalnych jest niejednoznaczny i zależy od poziomu rozwoju gospodarczego analizowanych krajów.

Zdaniem Imbs (2004) stopień podobieństwa struktur gospodarczych (przemysłowych) oraz stopień specjalizacji wpływaja na stopień synchronizacji cykli koniunkturalnych skoro szoki ekonomiczne dotyczące danej dziedziny przemysłu powodują więk- szy wzrost synchronizacji cykli koniunkturalnych w krajach o zbliżonych strukturach produkcji niż w gospodarkach o asymetrycznych strukturach produkcji.

Według De Haan, Inklaar, Jong-a-Pin (2008), jeśli cykle koniunkturalne w krajach tworzących unię monetarną nie są wystarczająco zbieżne, prowadzenie wspólnej polityki pieniężnej może nie być optymalne dla wszystkich zainteresowanych krajów.

\section{Wyniki wybranych analiz empirycznych dotyczących synchronizacji cykli koniunkturalnych}

W najnowszej literaturze ekonomicznej dotyczącej handlu międzynarodowego główny nacisk kładzie się na problematykę wpływu integracji handlowej krajów na synchronizację ich cykli koniunkturalnych (Akin, 2006).

Badania empiryczne związane $\mathrm{z}$ tą problematyką opierają się na dwóch alternatywnych podejściach. Pierwsza grupa badań empirycznych koncentruje się na analizie stopnia synchronizacji cykli koniunkturalnych w czasie, w wybranych krajach lub grupach krajów, natomiast druga grupa badań dotyczy analizy najważniejszych czynników determinujących stopień synchronizacji cykli koniunkturalnych w różnych gospodarkach.

Rysunek 2. Kanały wpływu intensywności handlu międzynarodowego na synchronizację cykli koniunkturalnych

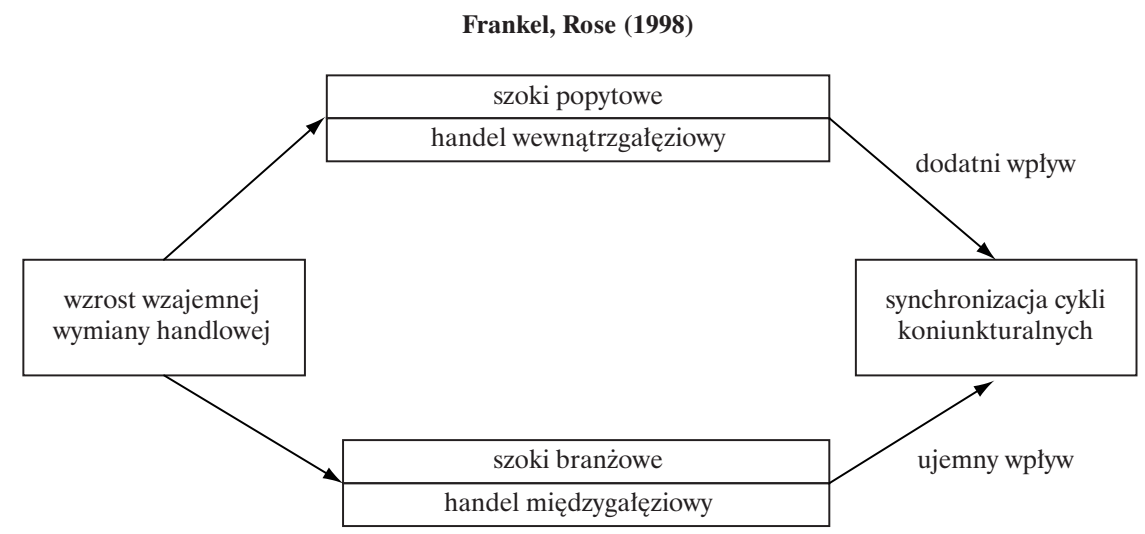

Kenen (1969), Krugman (1993)

Źródło: Rana, Cheng, Chia (2011). 
Frankel i Rose (1998) wykazali występowanie istotnego i pozytywnego związku między intensywnością handlu międzynarodowego oraz korelacją cykli koniunkturalnych w krajach członkowskich Organizacji Współpracy Gospodarczej i Rozwoju (OECD) w okresie 1959-1993. Jednakże Kenen (2000) twierdzi, że wyniki badań empirycznych przeprowadzonych przez Frankel i Rose (1998) należy interpretować ostrożnie, ponieważ wysoka korelacja produkcji w dwóch krajach prowadzi do zwiększenia intensywności powiązań handlowych między tymi krajami, ale nie musi to oznaczać ograniczenia występowania szoków asymetrycznych w tych gospodarkach.

De Haan, Inklaar oraz Jong-A-Pin (2005), analizując związek między intensywnością handlu międzynarodowego i synchronizacja cyklu koniunkturalnego dla 21 krajów członkowskich OECD w okresie 1970-2003, potwierdzili dodatni wpływ intensywności handlu międzynarodowego na synchronizacje cykli koniunkturalnych, ale efekt ten okazał się znacznie mniejszy niż sugerowany przez Frankel i Rose (1998).

Wyniki przeprowadzonych badań empirycznych ujawniły, że integracja handlowa była głównym czynnikiem synchronizacji cykli koniunkturalnych w krajach islamskich, zwłaszcza w okresie 1990-2005. Ponadto, podobieństwa polityki fiskalnej i monetarnej, jak również zbliżone struktury ekonomiczne krajów miały istotny i pozytywny wpływ na synchronizację cykli koniunkturalnych (Karimi i Pirasteh, 2009).

Calderón, Chong i Stein (2002) analizowali wpływ intensywności handlu zagranicznego na synchronizację cykli koniunkturalnych w 147 krajach w okresie 1960-1999. Wyniki przeprowadzonych badań wskazywały, że kraje o wyższej intensywności dwustronnej wymiany handlowej charakteryzowały się większym stopniem synchronizacji cykli koniunkturalnych, a wpływ integracji handlowej na synchronizację cykli koniunkturalnych był większy w krajach wysoko rozwiniętych gospodarczo niż w krajach rozwijajacych się. Co więcej, wpływ intensywności wymiany handlowej na korelacje cykli koniunkturalnych był tym mniejszy, im większy był stopień asymetrii struktury produkcji między badanymi krajami.

Z kolei, wyniki analiz empirycznych przeprowadzonych przez Shin i Wang (2003) dla dwunastu krajów Azji Wschodniej ujaw- niły, że handel wewnątrzgałęziowy stanowił główny kanał, poprzez który następowała synchronizacja cykli koniunkturalnych tych gospodarek. Jednakże samo zwiększenie handlu międzynarodowego ogółem nie musi prowadzić do większej synchronizacji cykli koniunkturalnych. Sytuacja ta wynika z faktu, że wzrostowi całkowitych obrotów handlowych krajów towarzyszy najczęściej rozwój wymiany międzygałęziowej, która z kolei prowadzi do specjalizacji i różnicowania struktur produkcji poszczególnych krajów (Lubiński, 2007).

Bayoumi i Eichengreen (1992) twierdzą, że kraje Unii Europejskiej można podzielić na dwie grupy, tzn. na kraje dominujące (rdzenia), charakteryzujące się występowaniem podobnych szoków ekonomicznych oraz kraje peryferyjne cechujące się wystepowaniem szoków asymetrycznych. Kraje dominujące odznaczają się bardziej zdywersyfikowaną strukturą gospodarki i wysoką intensywnością handlu wewnątrzgałęziowego, natomiast kraje peryferyjne są wysoce wyspecjalizowane w handlu międzygałęziowym.

Wyniki badań przeprowadzonych przez Matkowskiego i Próchniaka (2009) sugerują, że kraje Europy Środkowo-Wschodniej ujawniają znaczną zbieżność cykli koniunkturalnych w stosunku do Europy Zachodniej, a w szczególności do strefy euro. Zdaniem wspomnianych autorów, synchronizacja ta jest szczególnie wysoka w krajach Europy Środkowej (Polska, Węgry, Czechy, Słowacja i Słowenia), znacznie zaś niższa w krajach bałtyckich (Litwa, Łotwa i Estonia) oraz w krajach bałkańskich (Rumunia i Bułgaria). Rosnaca zbieżność wahań koniunkturalnych krajów Europy Środkowo-Wschodniej w stosunku do Europy Zachodniej jest konsekwencja postępującego procesu integracji gospodarczej, rosnącej wymiany handlowej i kapitałowej oraz rosnącej koordynacji polityki gospodarczej w ramach Unii Europejskiej.

Natomiast, zgodnie z wynikami badań przeprowadzonymi przez Krugmana (1991), proces integracji gospodarczej prowadzi do bardziej asymetrycznych wahań koniunkturalnych, czego skutkiem jest mniejsza synchronizacja cykli koniunkturalnych. Również wyniki badań przeprowadzonych przez Camacho, Perez-Quiros i Saiz (2006) sugerują, że integracja gospodarcza prowadzi do zwiększenia regionalnej koncentracji działalności gospodarczej, 
czego skutkiem jest powstawanie sektorowych lub regionalnych szoków ekonomicznych, zwiększających prawdopodobieństwo pojawiania się szoków asymetrycznych oraz rozbieżnych cykli koniunkturalnych.

Reasumując, wyniki zdecydowanej większości przeprowadzonych analiz empirycznych wskazują, że wpływ wzrostu obrotów handlowych między krajami na synchronizację cykli koniunkturalnych tych krajów zależy nie tylko od intensywności powiązań handlowych, lecz także od struktury wymiany handlowej. Mianowicie, jeśli w obrotach handlowych krajów dominuje handel wewnątrzgałęziowy, należy oczekiwać występowania szoków symetrycznych i tym samym większej synchronizacji cykli koniunkturalnych tych krajów. Jeśli jednak w obrotach handlowych dominuje handel międzygałęziowy, wówczas należy oczekiwać częstszego występowania szoków asymetrycznych i mniejszej synchronizacji cykli koniunkturalnych (Kose i Yi, 2005).

\section{Handel międzynarodowy a synchronizacja cykli koniunkturalnych w ujęciu modelowym}

W literaturze ekonomicznej dokonuje się najczęściej pomiaru oddziaływania integracji handlowej na synchronizację cykli koniunkturalnych w krajach lub grupach krajów za pomocą modelu zaproponowanego przez Frankel i Rose (1998), przedstawiającego się poniższym równaniem:

$$
\operatorname{Corr}_{i j t}=c+\alpha \operatorname{Trade}_{i j t}+\varepsilon_{i j t},
$$

gdzie:

Corr $_{i j t}$ - synchronizacja cykli koniunkturalnych krajów $i$ oraz $j$ w okresie $t$;

Trade $_{i j t}$ - intensywność wymiany handlowej krajów $i$ oraz $j$ w okresie $t$;

$\alpha \quad$ - współczynnik oddziaływania intensywności wymiany handlowej krajów $i$ oraz $j$ na synchronizację ich cykli koniunkturalnych;

c - wyraz wolny równania;

$\varepsilon_{i j t} \quad-$ składnik losowy.

Do pomiaru stopnia synchronizacji cykli koniunkturalnych krajów wykorzystuje się indeks synchronizacji cykli koniunkturalnych (Business Cycles Synchronization $B C S$ ) skonstruowany przez Frankel, Rose
(1998) oraz Akin (2006) i przedstawiający się następującym wyrażeniem:

$$
\operatorname{corr}_{i j}=\frac{\operatorname{cov}\left(y_{i}^{c}, y_{j}^{c}\right)}{\sqrt{\operatorname{var}\left(y_{i}^{c}\right)_{\operatorname{var}}\left(y_{j}^{c}\right)}},
$$

gdzie:

$y_{i}^{c}-$ logarytm realnej dynamiki produktu krajowego brutto w kraju $i$, po usunięciu trendu za pomocą filtru HodrickaPresscotta;

$y_{j}^{c}-$ logarytm realnej dynamiki produktu krajowego brutto w kraju $j$, po usunięciu trendu za pomocą filtru HodrickaPresscotta.

Dodatnia wartość współczynnika BCS świadczy o występowaniu synchronizacji cykli koniunkturalnych między dwoma krajami $i$ oraz $j$. Natomiast ujemna wartość wskaźnika BCS oznacza brak synchronizacji cykli koniunkturalnych między krajami $i$ oraz $j$.

Z kolei, intensywność wymiany handlowej mierzy się za pomocą wskaźnika intensywności handlu (Trade Intensity Index - TII) skonstruowanego przez Drysdel, Garnaut (1993) i Yeats (1997) i przedstawionego poniższym wyrażeniem:

$$
T I I_{i j}=\frac{\left(\frac{X_{i j}}{X_{i w}}\right)}{\left(\frac{M_{j w}}{M_{w w}}\right)},
$$

gdzie:

$\left(X_{i j} / X_{i w}\right)$ - stosunek eksportu kraju $i$ do kraju $j$ do całkowitego eksportu kraju $i$;

$\left(M_{j w} / M_{w w}\right)$ - stosunek całkowitego importu kraju $j$ do całkowitego importu światowego.

Wskaźnik intensywności handlu jest wykorzystywany do określenia czy wartość wymiany handlowej między dwoma krajami jest większa lub mniejsza, niż można byłoby oczekiwać na podstawie ich znaczenia w handlu światowym. Indeks ten może przyjmować wartości większe lub mniejsze od jedności. Wartość wskaźnika wyższa (niższa) od jedności świadczy o tym, że dwustronna wymiana handlowa jest większa (mniejsza) niż oczekiwano, uwzględniając znaczenie kraju partnerskiego w handlu światowym.

Natomiast o kształtowaniu się komplementarności gospodarczej krajów i inten- 
sywności handlu wewnątrzgałęziowego świadczy kształtowanie się stopnia dopasowania struktury podaży eksportowej do struktury popytu importowego krajów. Chodzi o tzw. wskaźnik komplementarności handlowej (Complementarity rate of exporter - Se) będący sumą wartości bezwzględnej różnicy udziałów importu i eksportu (wg 3-cyfrowej klasyfikacji SITC) w krajach objętych badaniem, podzieloną przez dwa.

$$
S e_{j k}=\frac{\sum_{i}\left|E_{i j}-M_{i k}\right|}{2},
$$

gdzie:

$S e_{j k}$ - indeks komplementarności handlowej eksportera $j$ w stosunku do importera $k$;

$i \quad$ - grupa towarowa wg trzycyfrowej klasyfikacji SITC;

$j \quad$ - eksporter (grupa krajów lub kraj);

$k$ - importer (grupa krajów lub kraj);

$E_{i j}-$ udział grupy towarowej $i$ w eksporcie ogółem kraju $j$;

$M_{i k}-$ udział grupy towarowej $i$ w imporcie ogółem kraju $k$.

Wskaźnik komplementarności handlowej eksportera może przyjmować wartości między 0 a 1. Zerowa wartość wskaźnika oznacza, że nie istnieje związek między strukturą eksportu kraju $j$ i strukturą importu kraju k. Z kolei, wskaźnik równy 1 wskazuje na doskonałe dopasowanie struktur eksportu i importu badanych krajów.

W celu analizy oddziaływania stopnia intensywności wymiany handlowej na syn- chronizację cykli koniunkturalnych w Polsce i Unii Europejskiej w okresie 1995-2011 wykorzystano model bazujący na modelu Frankel i Rose (1998), który ostatecznie przedstawiają się w poniższy sposób:

$$
\operatorname{Corr}_{P L_{-} U E}=c+\alpha \operatorname{TII}_{U E}+\operatorname{Se}_{U E}+\varepsilon_{U E},
$$

gdzie:

$\operatorname{Corr}_{P L}{ }_{U E}$ - wskaźnik synchronizacji cykli koniunkturalnych Polski i Unii Europejskiej;

$T I I_{U E} \quad$ - wskaźnik intensywności handlu Polski z Unią Europejską;

$\mathrm{Se}_{U E} \quad$ - wskaźnik komplementarności handlowej Polski w stosunku do Unii Europejskiej.

Wszystkie wymienione powyżej zmienne miały częstotliwość roczną i obejmowały okres od 1995 do 2011 roku. Zgodnie z rysunkiem $3 \mathrm{w}$ przypadku większości lat z okresu 1995-2011 miały miejsce dodatnie wartości współczynników synchronizacji cykli koniunkturalnych Polski i Unii Europejskiej, co świadczyło o występowaniu stosunkowo wysokiej synchronizacji cykli koniunkturalnych między Polską i Unią Europejską. Natomiast ujemne wartości wskaźników synchronizacji cykli koniunkturalnych świadczace o braku synchronizacji cykli koniunkturalnych występowały głównie w okresach spowolnienia gospodarczego wywołanego różnymi kryzysami gospodarczymi (rys. 3).

Z kolei, na podstawie rysunku 4 można zauważyć, iż intensywność wymiany handlowej Polski z Unią Europejską wykazywała

Rysunek 3. Współczynniki synchronizacji cykli koniunkturalnych (BCS) Polski z Unią Europejską w okresie 1995-2011

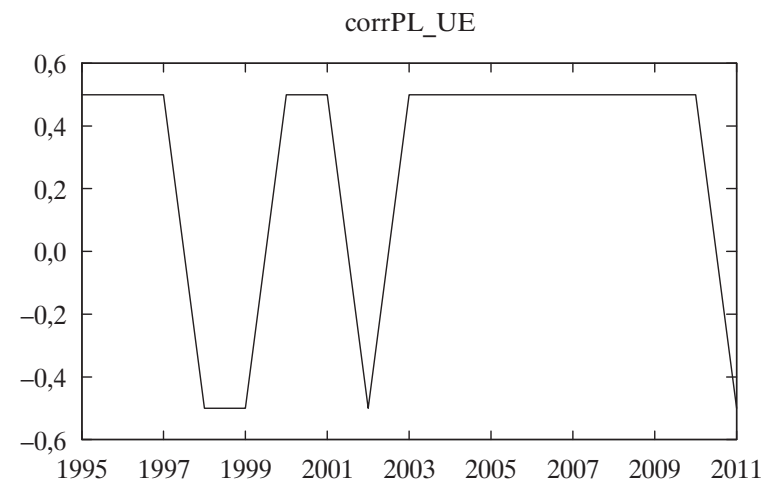

Źródło: opracowanie własne na podstawie danych UNCTAD (2012).

Wydział Zarządzania UW DOI 10.7172/1733-9758.2014.17.6 
Rysunek 4. Wskaźniki intensywności wymiany handlowej (TII) Polski z Unią Europejską w okresie 1995-2011

TII_UE

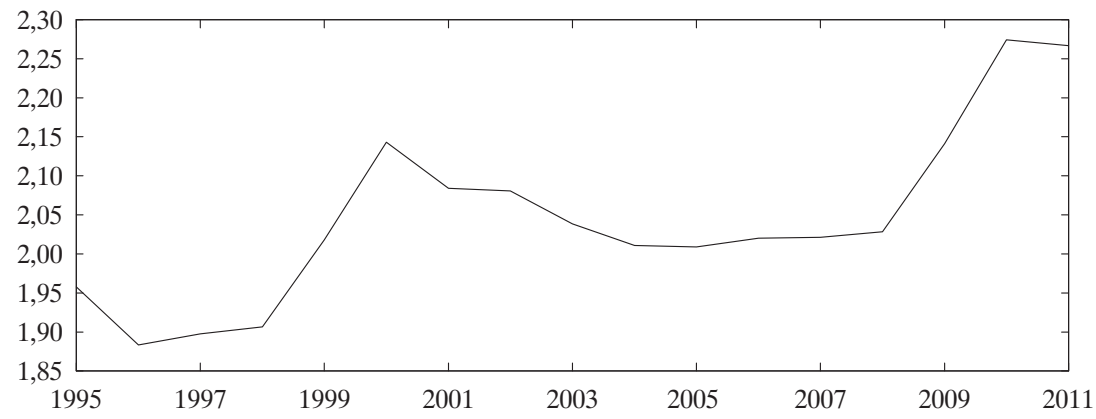

Źródło: opracowanie własne na podstawie danych UNCTAD (2012).

tendencję wzrostową w okresie 1995-2011, przy czym największy wzrost wskaźnika intensywności handlu zaobserwowano w trakcie trzech ostatnich lat badanego okresu (rys. 4).

Natomiast analizując kształtowanie się wskaźników komplementarności handlowej Polski z Unią Europejską w okresie 19952011 można zauważyć systematyczny wzrost wartości wskaźników w badanym okresie z wyjątkiem lat 2000-2003, co świadczyło o wzroście intensywności handlu wewnątrzgałęziowego między badanymi gospodarkami (rys. 5).

Przed dokonaniem estymacji modeli wyjaśniających wpływ integracji handlowej na synchronizację cykli koniunkturalnych Polski i Unii Europejskiej niezbędne było określenie stacjonarności wykorzystywanych szeregów czasowych, gdyż nieuwzględ- nienie ewentualnego braku stacjonarności szeregów czasowych mogłoby spowodować wstępowanie regresji pozornej między zmiennymi. W tym celu wykorzystano rozszerzony test Dickeya-Fullera - ADF (Augmented Dickey-Fuller). Wyniki rozszerzonego testu ADF wskazywały na występowanie szeregów czasowych o rzędach integracji 0 i 1. Odpowiednie wyniki testów ADF przedstawiono w tabeli 1 .

Brak stacjonarności kilku szeregów czasowych uwzględnianych w modelach wymusił modyfikację postaci funkcyjnej modeli. W przypadku wektora autoregresji modyfikacja polegała na zastąpieniu wielkości analizowanych zmiennych przez ich pierwsze różnice. Jednocześnie ze względu na brak występowania pierwiastka jednostkowego we wszystkich szeregach czasowych oraz brak kointegracji między zmiennymi

Rysunek 5. Wskaźniki komplementarności handlowej (Se) Polski z Unią Europejską w okresie 1995-2011

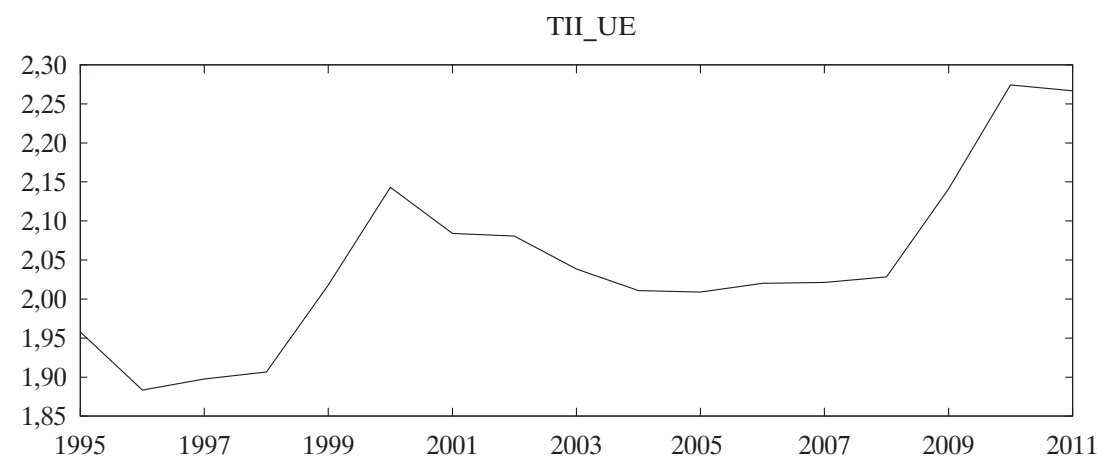

Źródło: opracowanie własne na podstawie danych UNCTAD (2012). 
Tabela 1. Wyniki analizy stacjonarności poszczególnych szeregów czasowych modelu VAR

\begin{tabular}{|l|c|}
\hline \multicolumn{1}{|c|}{ Szereg czasowy } & Rząd integracji \\
\hline Corr $_{P L_{-} U E t} \begin{array}{c}\text { - wskaźnik synchronizacji cykli koniunkturalnych Polski i Unii } \\
\text { Europejskiej }\end{array}$ & $\mathrm{I}(0)$ \\
\hline$T I I_{U E t} \quad-$ wskaźnik intensywności handlu Polski z Unią Europejską & $\mathrm{I}(1)$ \\
\hline$S e_{U E t} \quad \begin{array}{l}\text { - wskaźnik komplementarności handlowej Polski w stosunku do } \\
\text { Unii Europejskiej }\end{array}$ & $\mathrm{I}(1)$ \\
\hline
\end{tabular}

Źródło: opracowanie własne.

modelu, nie było możliwości rozszerzenia i przekształcenia modeli w wektorowe modele korekty błędem.

W analizie przyjęto jeden okres opóźnień między zmiennymi objaśniającymi a zmienną objaśnianą (jeden rok). Dokonany wybór rzędu opóźnień był zgodny z wynikami kryteriów informacyjnych modelu Akaike, Schwartza-Bayesiana oraz Hannana-Quinna. Według tych kryteriów największą pojemność informacyjną miał model z jednym opóźnieniem.

Następnie dokonano estymacji modeli za pomocą modelu wektorowej autoregresji (Vector Autoregression Model) zaproponowanego przez Simsa (1980). W metodzie VAR analizuje się dane zjawisko za pomocą układu równań, co zgodnie z postulatem Simsa (1980) eliminuje jednocześnie problem egzogeniczności zmiennych objaśniających. W tabeli 2 przedstawiono wyniki oszacowań parametrów modelu VAR.

Na podstawie wyników oszacowań równania 1 można zauważyć, iż synchronizacja cykli koniunkturalnych Polski i Unii Europejskiej była $\mathrm{w}$ badanym okresie $\mathrm{w}$ istotnym stopniu zdeterminowana kształtowaniem się intensywności wymiany handlowej oraz komplementarności handlowej Polski i Unii Europejskiej. Obliczony współczynnik oddziaływania intensywności wymiany handlowej na zbieżność cykli koniunkturalnych wyniósł $-0,61$, co tym samym potwierdzało negatywny wpływ handlu na korelację cykli koniunkturalnych Polski i Unii Europejskiej. Natomiast współczynnik oddziaływania komplementarności handlowej na synchronizację cykli koniunkturalnych wyniósł 2,52 , co tym razem świadczyło o pozytywnym wpływie handlu wewnątrzgałęziowego na zbieżność cykli koniunkturalnych badanych gospodarek.

Zatem wyniki przeprowadzonych badań były zgodne $\mathrm{z}$ ujęciem teoretycznym wskazującym na negatywny/pozytywny wpływ handlu międzygałęziowego/wewnątrzgałęziowego na synchronizację cykli koniunkturalnych analizowanych krajów. Uzyskane

Tabela. 2. System VAR (model wektorowej autoregresji), rząd opóźnienia 1. Estymacja KMNK dla obserwacji 1996-2011

\begin{tabular}{|c|c|c|c|c|}
\hline \multicolumn{4}{|c|}{ Równanie 1: corrPL_UE } & \\
\hline & \multicolumn{2}{|c|}{ Wspótczynnik } & t-Studenta & \\
\hline corrPL_UE_1 & \multicolumn{2}{|c|}{0,113260} & 0,340418 & \\
\hline TII_UE_1 & \multicolumn{2}{|c|}{$-0,609078$} & $-1,290910$ & \\
\hline Se_UE_1 & \multicolumn{2}{|c|}{2,518280} & 4,533860 & \\
\hline Średn. aryt. zm. zależnej & 0,250000 & \multicolumn{2}{|c|}{ Odch. stand. zm. zależnej } & 0,447214 \\
\hline Suma kwadratów reszt & 2,916527 & \multicolumn{2}{|c|}{ Błąd standardowy reszt } & 0,473654 \\
\hline Wsp. determ. R-kwadrat & 0,270868 & \multicolumn{2}{|c|}{ Skorygowany R-kwadrat } & 0,158694 \\
\hline $\mathrm{F}(3,13)$ & 1,609809 & \multicolumn{2}{|c|}{ Wartość p dla testu F } & 0,235149 \\
\hline Autokorel. reszt - rho1 & $-0,019653$ & \multicolumn{2}{|c|}{ Stat. Durbina-Watsona } & 1,826721 \\
\hline
\end{tabular}

Źródło: opracowanie własne.

Wydział Zarządzania UW DOI 10.7172/1733-9758.2014.17.6 
Rysunek 6. Wykresy funkcji odpowiedzi impulsowych wskaźnika synchronizacji cykli koniunkturalnych Polski i Unii Europejskiej
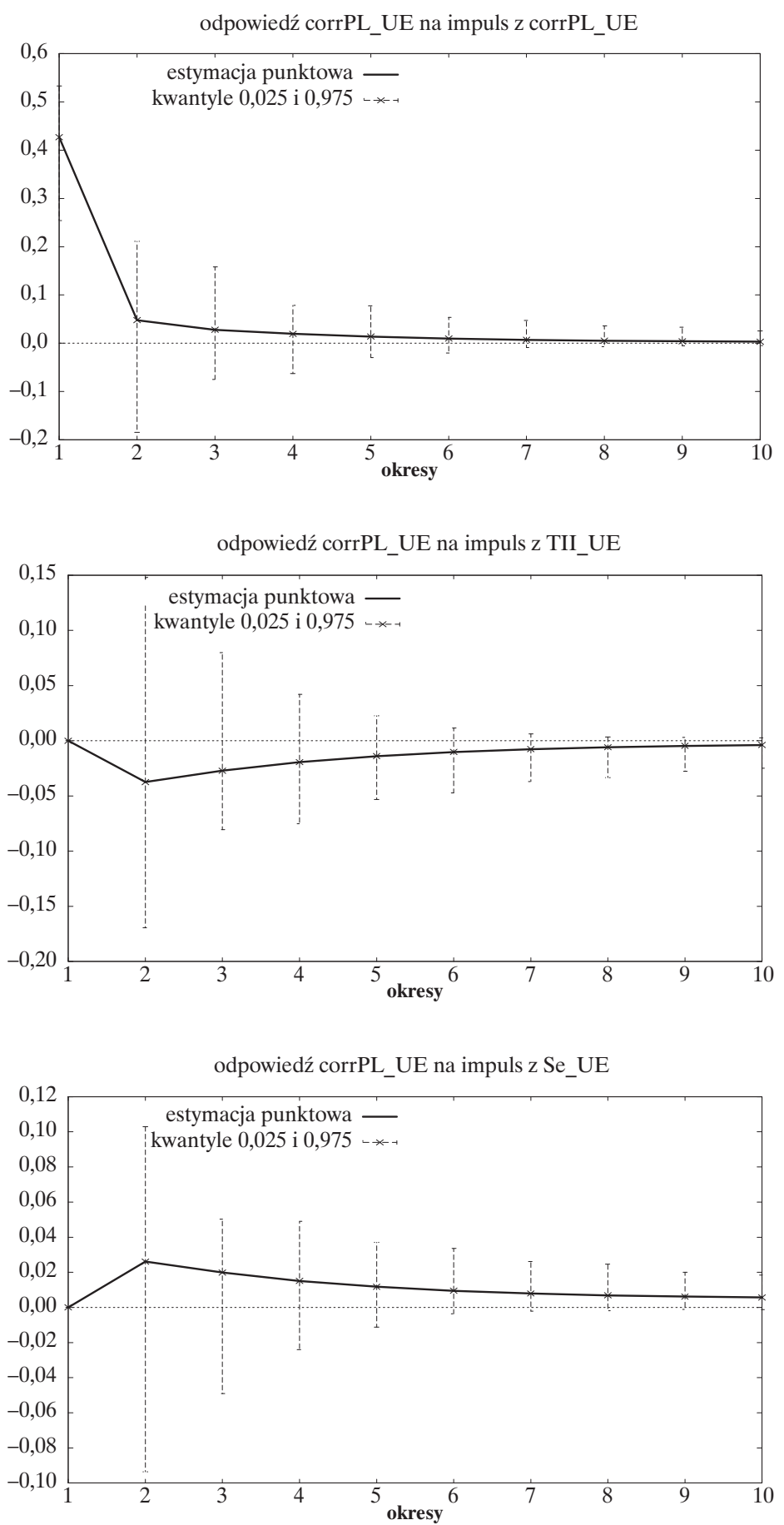

Źródło: opracowanie własne. 
rezultaty badań są również zbieżne z wynikami badań empirycznych przeprowadzonymi przez Camacho, Perez-Quiros i Saiz (2006) oraz Shin i Wang (2003).

Nastepnym etapem badania był pomiar siły oddziaływania analizowanych współczynników na synchronizację cykli koniunkturalnych Polski, Unii Europejskiej w okresie 1995-2011. Pomiaru tego dokonano za pomocą tzw. funkcji odpowiedzi impulsowych (impulse response function), czyli funkcji reakcji wskaźnika synchronizacji cykli koniunkturalnych na impuls w postaci zmiany wskaźników intensywności wymiany handlowej i komplementarności handlowej Polski i Unii Europejskiej (rys. 6).

$\mathrm{Na}$ podstawie powyższych rysunków można zauważyć, iż szokowy wzrost wskaźnika synchronizacji cykli koniunkturalnych Polski i Unii Europejskiej prowadził do natychmiastowego wzrostu wartości tego wskaźnika w ciągu pierwszego roku od momentu pojawienia się szoku, a następnie do spadku i stopniowej stabilizacji po upływie kolejnych czterech lat. Natomiast wzrost wskaźnika intensywności wymiany handlowej Polski z Unią europejską prowadził do stopniowego spadku wskaźnika synchronizacji cykli koniunkturalnych badanych gospodarek w ciągu dwóch kolejnych lat od momentu wystąpienia szoku, a następnie do stopniowego wzrostu i stabilizacji w trakcie kolejnych sześciu lat. Odmiennie reagował wskaźnik synchronizacji cykli koniunkturalnych Polski i Unii Europejskiej na wzrost wskaźnika komplementarności handlowej analizowanych gospodarek. Mianowicie, szokowy wzrost wartości wskaźnika komplementarności handlowej prowadził do stopniowego wzrostu wskaźnika synchronizacji cykli koniunkturalnych Polski i Unii Europejskiej, a następnie do stopniowego spadku i stabilizacji po upływie kolejnych pięciu lat.

\section{Zakończenie}

Przeprowadzone badania empiryczne dotyczącej wpływu handlu zagranicznego na synchronizację cykli koniunkturalnych Polski i Unii Europejskiej wykazały, że wzrost obrotów handlowych niekoniecznie prowadzi do zwiększenia synchronizacji cykli koniunkturalnych analizowanych gospodarek. Wpływ wzrostu handlu dwóch krajów na synchronizację ich cykli koniunkturalnych zależy nie tylko od intensywności wymiany handlowej, lecz także od struktury obrotów handlowych.

Wzrost wymiany handlowej prowadzi do większej zbieżności cykli koniunkturalnych tylko wtedy, kiedy jest to handel wewnatrzgałęziowy prowadzący do wzrostu komplementarności struktur gospodarczych krajów i przyczyniający się do powstawania symetrycznych szoków ekonomicznych. W przeciwnym razie, wzrost obrotów handlowych dwóch gospodarek może powodować wzrost specjalizacji i przyczyniać się do powstawania częstych szoków idiosynkratycznych (asymetrycznych).

Uzyskane wyniki badań mają istotne implikacje z punktu widzenia przyszłego członkostwa Polski w strefie euro. Mianowicie, skoro wzrost wymiany wewnątrzgałęziowej Polski i Unii Europejskiej (w tym strefy euro) prowadzi do większej korelacji cykli koniunkturalnych obu gospodarek, wówczas koszty związane z brakiem autonomicznej polityki monetarnej w obliczu idiosynkratycznych szoków ekonomicznych będą mniejsze w sytuacji członkostwa Polski w unii walutowej ${ }^{1}$. Tym samym korzyści netto wynikające $\mathrm{z}$ członkostwa Polski w unii walutowej okażą się większe w warunkach rosnącego stopnia komplementarności struktur gospodarczych Polski i strefy euro. Zatem, rezultaty badań mogą stanowić jeden $\mathrm{z}$ argumentów popierających dążenia Polski do pełnego członkostwa w unii monetarnej krajów członkowskich Unii Europejskiej.

\section{Przypis}

1 Pomimo że intensyfikacja wymiany handlowej pomiędzy krajami należącymi do wspólnego obszaru walutowego strefy euro sugeruje wzrost stopnia synchronizacji cykli koniunkturalnych i w dalszej konsekwencji konwergencję gospodarczą, to w przypadku części krajów brakuje wyraźnego potwierdzenia tej tezy. Sytuacja ta może być rezultatem braku spełnienia fundamentalnego założenia warunkującego konwergencję w obszarze walutowym, jakim jest doskonała mobilność siły roboczej, Ministerstwo Gospodarki, Departament Analiz i Prognoz (2011).

\section{Bibliografia}

Akin, C. (2006). Multiple Determinants of Business Cycle Synchronization. Washington: George Washington University, Department of Economics. Bayoumi, T. i Eichengreen, B. (1992). Shocking Aspects of European Monetary Unification. Natio- 
nal Bureau of Economic Research Working Papers, 3949, 1-39.

Calderón, C., Chong, A. i Stein, E. (2002). Trade Intensity and Business Cycle Synchronization: Are Developing Countries Any Different? Central Bank of Chile Working Papers, 195, 1-34.

Camacho, M., Perez-Quiros, G. i Saiz, L. (2006). Are European business cycles close enough to be just one?, Journal of Economics Dynamics and Control, 30, 1-31.

De Haan, J., Inklaar, R.C. i Jong-A-Pin, R.M. (2008). Will business cycles in the Euro area converge? A critical survey of empirical research, Journal of Economic Surveys, 22, 1-44.

De Haan, J., Inklaar, R. i Jong-a-Pin, R.M. (2005). Trade and Business Cycle Synchronization in OECD Countries - a Re-examination. CESifo Working Paper Series, 1546, 1-35.

Ministerstwo Gospodarki, Departament Analiz i Prognoz (2011). Konwergencja czy dywergencja gospodarcza w strefie euro? Warszawa, grudzień, 1-17. Drysdel, P. i Garnaut, R. (1993). The Pacific: An Application of General Theory of Economic Integration. W: Bergsten F. i Noland M. (eds.). Pacific Dynamism and International Economic System. Washington: Institute for International Economics.

Frankel, J. i Rose, A. (1998). The Endogenity of the Optimum Currency Area Criteria, The Economic Journal, 108, 1009-1025.

Grigoli, F. (2011). The Impact of Trade Integration on Business Cycle Synchronization for Mercosur Countries, The European Journal of Comparative Economics, 9(1), 103-131.

Imbs, J. (2004). Trade, Finance, Specialization, and Synchronization, Review of Economics and Statistics, 86, 723-734.

Karimi, F. i Pirasteh, H. (2009). Relationship between Economic Integration and Business Cycle
Synchronization, International Journal of Business and Development Studies, 1(1), 67-82.

Kenen, P.B. (1969). The Optimum Currency Area: An Eclectic View. W: Mundell R. i Swoboda, A.K. (eds.). Monetary Problems of the International Economy. Chicago: University of Chicago Press.

Kenen, P.B. (2000). Currency Areas, Policy Domains and the Institutionalization of Fixed Exchange Rates. CEP Discussion Papers, 0467, 1-39.

Kose, M.A. i Yi, K. M. (2005). Can the Standard International Business Cycle Model Explain the Relation Between Trade and Comovement? Federal Reserve Bank of Philadelphia Working Paper, 05-3, 1-40.

Krugman, P.R. (1991). Geography and Trade. Cambridge, Massachusetts: MIT Press.

Lubiński, M. (2007). Międzynarodowy cykl koniunkturalny, Contemporary Economics, 1(2), 5-19.

Matkowski, Z. i Próchniak M. (2009). Zbieżność rozwoju gospodarczego Polski i innych krajów Europy Srodkowo-Wschodniej w stosunku do Unii Europejskiej, Zarzadzanie Ryzykiem, 30, 53-97.

Rana, P.B., Cheng, T. i Chia, W.M. (2011). Trade Intensity and Business Cycle Synchronization: East Asia vs Europe, Journal of Asian Economics, 20 , 701-706.

Shin, K. i Wang, Y. (2003). Trade Integration and Business Cycle Synchronisation in East Asia, ISER Discussion Paper, 574, 1-38.

Sims. Ch.A. (1980). Macroeconomics and Reality, Econometrica, 1, 1-48.

UNCTAD (2012). Handbook of Statistics. New York and Geneva.

Yeats, A.J. (1997). Does MERCOSUR Trade Performance Raise Concerns About The Effects of Regional Trade Arrangements? The World Bank Economic Review, 12, 1-46. 


\section{Załączniki}

Załącznik 1. Dynamika realnego PKB w Polsce i Unii Europejskiej w okresie 1995-2011 (w \%)

PKB_PL

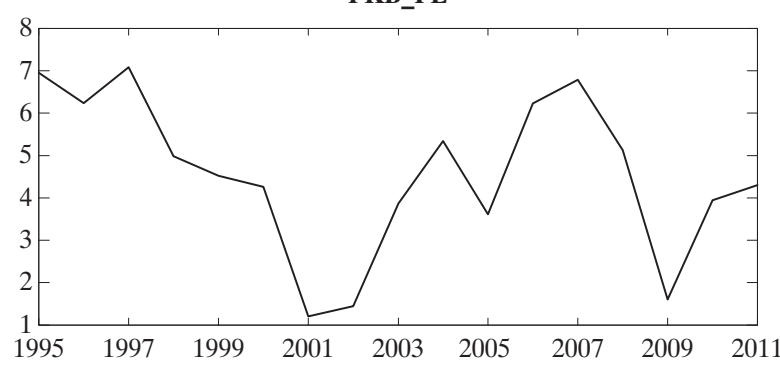

PKB_EU

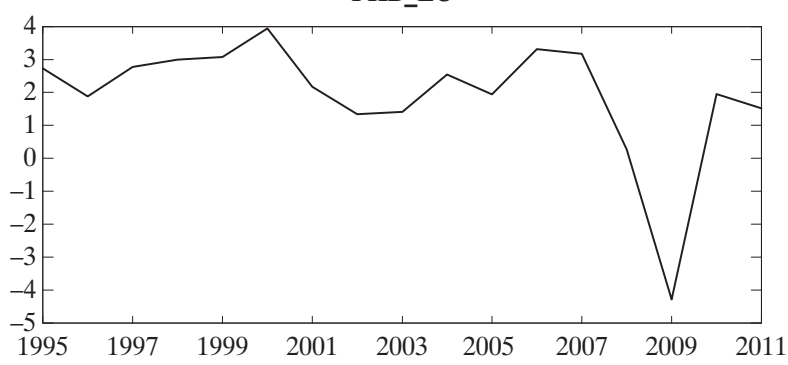

Źródło: UNCTAD (2012).

Załącznik 2. Wartość eksportu Polski ogółem oraz eksportu Polski do Unii Europejskiej (w mld USD)
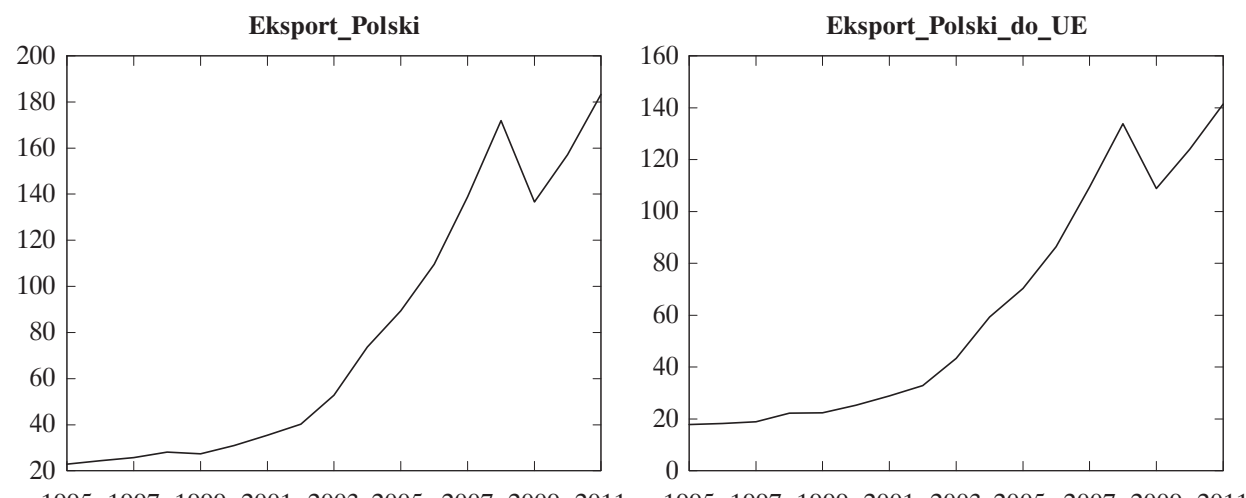

199519971999200120032005200720092011

199519971999200120032005200720092011

Źródło: UNCTAD (2012). 